\title{
Light Effects on Wax Begonia: Photosynthesis, Growth Respiration, Maintenance Respiration, and Carbon Use Efficiency
}

\author{
Krishna S. Nemali and M.W. van Iersel ${ }^{1}$ \\ Department of Horticulture, Miller Plant Sciences Building, the University of Georgia, Athens, GA \\ 30602-7273
}

AdDitional Index words. Begonia semperflorens, daily light integral, growth rate, light compensation point, photosynthetic photon flux

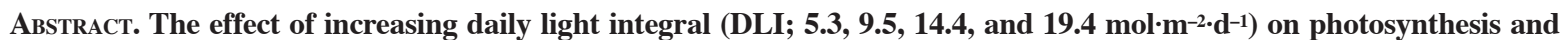
respiration of wax begonia (Begonia semperflorens-cultorum Hort.) was examined by measuring $\mathrm{CO}_{2}$ exchange rates (CER) for a period of $25 \mathrm{~d}$ in a whole-plant gas exchange system. Although plant growth rate (GR, increase in dry weight per day) increased linearly with increasing DLI, plants grown at low DLI $\left(5.3 \mathrm{or} 9.5 \mathrm{~mol} \cdot \mathrm{m}^{-2} \cdot \mathrm{d}^{-1}\right)$ respired more carbohydrates than were fixed in photosynthesis during the early growth period (13 and $4 \mathrm{~d}$, respectively), resulting in a negative daily carbon gain (DCG) and GR. Carbon use efficiency [CUE, the ratio of carbon incorporated into the plant to $\mathrm{C}$ fixed in gross photosynthesis $\left(P_{g}\right)$ ] of plants grown at low DLI was low, since these plants used most of the $C$ fixed in $P_{g}$ for maintenance respiration $\left(R_{m}\right)$, leaving few, if any, $C$ for growth and growth respiration $\left(R_{g}\right)$. Maintenance respiration accounted for a smaller fraction of the total respiration with increasing DLI. In addition, the importance of $R_{\mathrm{m}}$ in the carbon balance of the plants decreased over time, resulting in an increase in CUE. At harvest, crop dry weight $\left(\mathrm{DW}_{\mathrm{CROP}}\right)$ increased linearly with increasing DLI, due to the increased photosynthesis and CUE at high PPF.
\end{abstract}

Dry matter production and crop growth rate are strongly correlated to the amount of light intercepted by plants (Lawlor, 1995). To capture the maximum amount of radiation and optimize light use, shade-grown plants may undergo various physiological and morphological modifications. For example, a decrease in leaf number and an increase in specific leaf area (leaf area per unit leaf weight) with decreasing DLI have been reported in tall fescue [Festuca arundinacea Schreb. (Allard et al., 1991)] and dracaena [Dracaena sanderana hort Sander ex Mast(Vladimirova et al., 1997)], while a decrease in leaf number, leaf thickness, and stomatal number have been reported in mangosteen [Garcinia mangostana L. (Weibel et al., 1994)]. Other studies have reported modifications in photosynthetic (Norcini et al., 1991b) and respiration rates (Noguchi et al., 2001) in response to varying levels of DLI (Norcini et al., 1991b; Noguchi et al., 2001). However, the ability of shade grown plants to increase their photosynthesis when exposed to high photosynthetic photon flux $(P P F)$ is limited, because of relatively low levels of carboxylation enzymes and components of the electron transport chain (Björkman, 1981). Indeed, research has indicated a decrease in the quantum yield of shade plants grown under high DLI (Funnell et al., 2002).

Plant growth results when carbohydrates synthesized in photosynthesis exceed those lost in respiration. Experimental evidence indicates that $30 \%$ to $50 \%$ of carbohydrates synthesized in photosynthesis are lost in respiration during crop growth (Amthor, 1984; Lawlor, 1995; van Iersel and Seymour, 2000). Therefore, the significance of respiration in plant growth should not be underestimated. Research on whole-plant respiration has increased since Hesketh et al. (1971) and McCree (1974) related respiration to $\mathrm{P}_{\mathrm{g}}$ and dry weight of plants, and separated it into maintenance and growth components. According to Penning de Vries (1975), $R_{m}$ involves release of energy (ATP) only for sub-

Received for publication 19 Mar. 2003. Accepted for publication 7 Jan. 2004. We thank Larry Freeman and Keven Calhoun for their technical support and Speedling Inc., Blairsville, Ga., for providing the plant material.

'Corresponding author; e-mail mvanier@uga.edu. cellular maintenance processes, whereas $R_{g}$ involves release of energy for all processes that result in a net increase in biomass. To understand the physiological basis of growth, both photosynthesis and respiration have to be studied. Although a large amount of literature is available on the effects of light on photosynthesis in shade plants (e.g., Callan and Kennedy, 1995; Funnell et al., 2002; Greenway and Lieffers, 1997; Norcini et al., 1991a, 1991b), few studies have focused on respiration, and $R_{g}$ and $R_{m}$ in particular, in shade plants grown at varying DLI levels.

Most of the commercially available equipment for measuring photosynthesis and respiration in plants is designed for leaf measurements. Traditional techniques of measuring leaf photosynthesis do not accurately determine the dry matter production and growth rate of plants (van Iersel and Bugbee, 2000). Continuous measurements of the CER of whole plants (for weeks) can depict the growth rate of plants more accurately than individual leaf measurements, as they directly measure accumulated C (a measure of growth rate) in plants (van Iersel and Kang, 2002). Although there have been other whole-plant photosynthesis studies in the genus Begonia (Giaglaras et al., 1995; Ehler and Hansen, 1998), these studies focused on short-term responses of photosynthesis to $P P F$. Short-term responses may differ greatly from long-term responses (weeks as opposed to minutes or hours), since many species have the ability to acclimate to different light levels. Effects of acclimation to light on plant growth and CER can only be determined by exposing plants to different light levels over a prolonged period. Here we measured whole-crop CER of wax begonia continuously for a period of $25 \mathrm{~d}$ in a 10 -chamber, whole-plant gas exchange system. The objective was to quantify the effects of various DLI levels on plant growth, photosynthesis, growth respiration, maintenance respiration, and CUE of wax begonia.

\section{Materials and Methods}

Plant material. Wax begonia ‘Cocktail Vodka’ plug seedlings 
were procured in cell flats ( 288 cells/flat) from a commercial grower (Speedling Inc., Blairsville, Ga.) on 13 June 2001. Seedlings were transplanted into 36-cell flats $(160 \mathrm{~mL} / \mathrm{cell}$, Jumbo 606; TLC polyform, Plymouth, Minn.) filled with a soilless growing medium (Fafard 2P; Fafard Co., Anderson, S.C.). About one gram of a $14 \mathrm{~N}-6.1 \mathrm{P}-11.6 \mathrm{~K}$ slow-release fertilizer (14-14-14 Osmocote, The Scotts Co., Marysville, Ohio) was added to the growing medium in each cell prior to transplanting. One cell in each flat was left empty for inserting an irrigation pipe, which was inserted through a hole in the side of the gas exchange chamber. Flats were placed in a watertight tray, lined with a double-layer of capillary mat (Vattex F capillary watering system, OS plastics, Norcross, Ga.). A portion of the capillary mat was hung over one side of the tray to allow excess water to drain. About $2 \mathrm{~L}$ of water was added to the trays at approximately weekly intervals. Immediately after transplanting, the plants were placed inside whole-plant gas exchange chambers $\left(0.32 \times 0.5 \times 0.6 \mathrm{~m}^{3}\right)($ van Iersel and Bugbee, 2000) arranged inside two growth chambers (model E-15; Conviron, Winnipeg, Canada). Ten gas exchange chambers were used in the experiment, two of which were controls without plants. The data from these empty chambers were used to correct the data for zero drift of the differential infra red gas analyzer (IRGA), as discussed below.

ENVIRONMENTAL CONTROL. Shielded, aspirated, type-T thermocouples were used to measure the air temperature inside all gas exchange chambers. The chamber temperature was maintained at $\approx 25^{\circ} \mathrm{C}$ with electric resistance heaters $(100 \mathrm{~W})$ controlled by a datalogger(CR10T; Campbell Sci., Logan, Utah) and relay driver (SDM-CD16AC; Campbell Sci.). Humidity probes (HTO-45R; Rotronic, Huntington, N.Y.) were placed in four of the gas exchange chambers. Average air temperature and relative humidity were $25 \pm 1{ }^{\circ} \mathrm{C}$ (constant) and $65 \%$ to $85 \% / 80 \%$ to $100 \%$ (light/dark period respectively). Environmental conditions (excluding DLI) were similar in all treatments.

Treatments. To obtain the required DLI levels, gas exchange chambers were covered with shade cloth of varying thickness. Before placing plants inside the chambers, the DLI at canopy height was measured simultaneously in eight chambers using quantum sensors (QSO; Apogee Instruments Inc., Logan, Utah) connected to a datalogger (CR10X; Campbell Sci.). The average DLI measured in different treatments were 5.3, 9.5, 14.4, and $19.4 \mathrm{~mol} \cdot \mathrm{m}^{-2} \cdot \mathrm{d}^{-1}$ [corresponding to instantaneous $P P F$ of 106 , 189,286 , and $385 \mu \mathrm{mol} \cdot \mathrm{m}^{-2} \cdot \mathrm{s}^{-1}$, respectively]. The light source was a mix of fluorescent and incandescent lamps. A photoperiod of $14 \mathrm{~h}$ was maintained inside the growth chambers.

CO $_{2}$ EXChange RATE measurements. Data were collected using a previously described whole-plant gas exchange system (van Iersel and Bugbee, 2000), which directly measures net-photosynthesis $\left(\mathrm{P}_{\mathrm{n}}, \mu \mathrm{mol} \cdot \mathrm{s}^{-1}\right)$ and dark respiration $\left(\mathrm{R}_{\mathrm{d}}, \mu \mathrm{mol} \cdot \mathrm{s}^{-1}\right)$ of each crop semi-continuously for $30 \mathrm{~s}$, once every $10 \mathrm{~min}$ (see Table 1 for an explanation and units of the measured and calculated variables). Measurement of CER in each chamber took 1 min per chamber, because an additional $30 \mathrm{~s}$ were needed to purge air from the previously measured chamber from the tubing, followed by a 30-s period of actual CER measurement. The CER was measured for $25 \mathrm{~d}$. About $0.4 \mathrm{~L} \cdot \mathrm{s}^{-1}$ of ambient air was blown into each gas exchange chamber by a rotary vane blower (DT 3.40; Becker, Cuyahoga Falls, Ohio). The air flow into each gas exchange chamber was measured using mass flow meters (GFM37-32; Aalborg Instruments and Controls, Monsey, N.Y.) and the $\mathrm{CO}_{2}$ concentration of air from the blower was measured with an IRGA (SBA-1; PP-systems, Haverhill, Mass.). The difference in the $\mathrm{CO}_{2}$ concentration of the incoming and exiting air from gas exchange chambers was measured with an IRGA in differential mode (LI-6262; LI-COR, Lincoln, Nebr.).

The CER $\left(\mu \mathrm{mol} \cdot \mathrm{s}^{-1}\right)$ was calculated as the product of mass flow (moles of air per second) and the difference in $\mathrm{CO}_{2}$ concentration of the air entering and exiting the chambers $\left(\mu \mathrm{mol} \cdot \mathrm{mol}^{-1}\right)$. Since the two empty control chambers did not contain plants, CER measured from these chambers is an estimate of the error due to zero drift of the IRGA. These errors were corrected by subtracting Table 1. Explanation of the various abbreviated parameters with their units and, where applicable, the equation from which they are derived.

\begin{tabular}{|c|c|c|c|}
\hline Abbreviation & Meaning & Units & Equation \\
\hline$\overline{\mathrm{CCG}}$ & Cumulative carbon gain & $\mathrm{mol}$ or $\mathrm{mol} \cdot \mathrm{m}^{-2}$ & 3 \\
\hline CER & Carbon exchange rate & $\mu \mathrm{mol} \cdot \mathrm{s}^{-1}$ & --- \\
\hline CUE & Carbon use efficiency & $\mathrm{mol} \cdot \mathrm{mol}^{-1}$ & 7 \\
\hline DCG & Daily carbon gain & $\mu \mathrm{mol} \cdot \mathrm{d}^{-1}$ & 2 \\
\hline DLI & Daily light integral & $\mathrm{mol} \cdot \mathrm{m}^{-2} \cdot \mathrm{d}^{-1}$ & --- \\
\hline $\mathrm{DLI}_{\text {cum }}$ & Cumulative daily light integral over entire the growing period & $\mathrm{mol} \cdot \mathrm{m}^{-2}$ & - \\
\hline $\mathrm{DW}_{0}$ & Estimated crop dry weight at start of experiment & $\mathrm{g}$ & 4 \\
\hline $\mathrm{DW}_{\text {crop }}$ & Crop dry weight & $\mathrm{g}$ & 4 \\
\hline $\mathrm{DW}_{\text {day }}$ & Crop dry weight on a specific day & $\mathrm{g}$ & 4 \\
\hline$f_{c}$ & Carbon content of the plant material & $g \cdot g^{-1}$ & 4 \\
\hline GR & Growth rate & $g \cdot d^{-1}$ & 5 \\
\hline $\mathrm{g}_{\mathrm{r}}$ & Growth respiration coefficient & $\mathrm{g} \cdot \mathrm{g}^{-1}$ or $\mathrm{mol} \cdot \mathrm{mol}^{-1}$ & 8,11 \\
\hline $\mathrm{m}_{\mathrm{r}}$ & Maintenance respiration coefficient & $\mathrm{g} \cdot \mathrm{g}^{-1} \cdot \mathrm{d}^{-1}$ or $\mathrm{mol} \cdot \mathrm{mol}^{-1} \cdot \mathrm{d}^{-1}$ & 8,11 \\
\hline$P_{g}$ & Gross photosynthesis & $\mu \mathrm{mol} \cdot \mathrm{s}^{-1}$ & 1 \\
\hline$P_{n}^{8}$ & Net photosynthesis & $\mu \mathrm{mol} \cdot \mathrm{s}^{-1}$ & --- \\
\hline$P P F$ & Photosynthetic photon flux & $\mu \mathrm{mol} \cdot \mathrm{m}^{-2} \cdot \mathrm{s}^{-1}$ & --- \\
\hline $\mathrm{R}_{\mathrm{CH} 2 \mathrm{O}}$ & Amount of glucose respired per day & $g \cdot d^{-1}$ & --- \\
\hline $\mathrm{R}_{\mathrm{d}}$ & Dark respiration & $\mu \mathrm{mol} \cdot \mathrm{s}^{-1}$ & --- \\
\hline $\mathrm{R}_{\mathrm{g}}$ & Growth respiration & $\mathrm{g} \cdot \mathrm{d}^{-1}$ & 9 \\
\hline $\mathrm{R}_{\mathrm{m}}$ & Maintenance respiration & $\mathrm{g} \cdot \mathrm{d}^{-1}$ & 10 \\
\hline $\mathrm{R}_{\text {spec }}$ & Specific respiration & $\mathrm{g} \cdot \mathrm{g}^{-1} \cdot \mathrm{d}^{-1}$ & 8 \\
\hline RGR & Relative growth rate & $\mathrm{g} \cdot \mathrm{g}^{-1} \cdot \mathrm{d}^{-1}$ & 6 \\
\hline
\end{tabular}


the average CER of the two empty gas exchange chambers from that of chambers containing plants. Although CER measurements were taken every $10 \mathrm{~min}$, only average values for $\mathrm{P}_{n}$ (averaged over the entire light period) and $\mathrm{R}_{\mathrm{d}}$ (dark-period average) are used here. Hence, daily average gross photosynthesis $\left(\mathrm{P}_{\mathrm{g}}, \mu \mathrm{mol} \cdot \mathrm{s}^{-1}\right)$ was calculated as

$\mathrm{P}_{\mathrm{g}}=\mathrm{P}_{\mathrm{n}}-\mathrm{R}_{\mathrm{d}}$

[Eq. 1].

Since $\mathrm{R}_{\mathrm{d}}$ was measured as the $\mathrm{CO}_{2}$ exchange rate, it is expressed as a negative value, hence a negative sign in the above equation. This equation assumes that respiration rates during the light and dark periods were equal (van Iersel and Bugbee, 2000). Since one mole of either $\mathrm{CO}_{2}$ or $\mathrm{CH}_{2} \mathrm{O}$ contain an equal amount of $\mathrm{C}, \mathrm{CER}$ data can be directly converted in glucose equivalents. Thus, the total amount of respired glucose per day $\left(\mathrm{R}_{\mathrm{CH} 2 \mathrm{O}}\right.$, $\mathrm{g}$ of $\mathrm{CH}_{2} \mathrm{O}$ per day) was calculated as $-\mathrm{R}_{\mathrm{d}} \times 30 \times 86,400 / 10^{6}(30$ is the molecular weight of $\mathrm{CH}_{2} \mathrm{O}, 86,400$ the number of seconds in a day, and $10^{6}$ converts $\mu \mathrm{mol}$ to $\mathrm{mol})$.

Daily carbon gain ( $\mu \mathrm{mol}$ of $\mathrm{C}$ per day or the net amount of $\mathrm{C}$ fixed by the 35 plants in a gas exchange chamber per day) was calculated as

$\mathrm{DCG}=\left(\mathrm{P}_{\mathrm{n}} \times \mathrm{t}_{\text {light }}\right)+\left(\mathrm{R}_{\mathrm{d}} \times \mathrm{t}_{\text {dark }}\right)$

where $t_{\text {light }}$ and $t_{\text {dark }}$ are the duration of the light and dark periods (s), respectively.

Integrating DCG over time $(\mathrm{t})$ provides an estimate of cumulative carbon gain $(\mathrm{CCG}$, mol of $\mathrm{C}$; the total amount of carbon accumulated in plants since the start of experiment, a measure of plant mass):

$\mathrm{CCG}=\mathrm{IDCG} \mathrm{dt}$

[Eq. 3]

Cumulative carbon gain at the end of the experiment was plotted against $\mathrm{DW}_{\mathrm{CROP}}(\mathrm{g})$ in each treatment, and a linear equation was fitted to describe the relationship:

$\mathrm{DW}_{\mathrm{CROP}}=\mathrm{DW}_{0}+12 \times \mathrm{CCG} / \mathrm{f}_{\mathrm{c}}$

where $\mathrm{DW}_{0}$ is the estimated initial dry weight of the plants before starting the experiment, 12 converts moles of carbon to grams of carbon, and $f_{c}$ is the estimated carbon content of the plants ( $g$ of $\mathrm{C} / \mathrm{g}$ of dry mass). Dry weight of plants at the end of each day $\left(\mathrm{DW}_{\text {day }}\right)$ in different treatments was estimated from this equation, based on the CCG of the plants.

To look at the effects of DLI on the efficiency with which light was used to fix $\mathrm{C}, \mathrm{CCG} / \mathrm{m}^{2}$ ground area was determined by dividing CCG by the ground area of the gas exchange chamber $\left(0.184 \mathrm{~m}^{2}\right)$. Cumulative DLI $\left(\mathrm{DLI}_{\mathrm{cum}}, \mathrm{mol} \cdot \mathrm{m}^{-2}\right)$ was determined by multiplying DLI by $25 \mathrm{~d}$ (duration of the gas exchange study), and $\mathrm{CCG} / \mathrm{DLI}_{\text {cum }}$ (mol of carbon fixed during the growing period per mol of incident light) was calculated from these data.

Growth rate ( $\mathrm{g}$ of dry mass per day) of plants in different treatments can be estimated from DCG $\left(\right.$ mold $\left.^{-1}\right)$ as

$\mathrm{GR}=12 \times \mathrm{DCG} / \mathrm{f}$

where 12 converts moles of carbon to grams of carbon.

Relative growth rate (RGR, g of new dry mass per $g$ of existing dry mass per day) of the plants was estimated from GR and $\mathrm{DW}_{\text {day }}$ :

$\mathrm{RGR}=\mathrm{GR} / \mathrm{DW}_{\text {day }}$

Carbon use efficiency (mol of $\mathrm{C}$ incorporated per mol of $\mathrm{C}$ fixed in gross photosynthesis) was calculated as follows:

$\mathrm{CUE}=\mathrm{DCG} /\left(\mathrm{P}_{\mathrm{g}} \times \mathrm{t}_{\text {light }}\right)$

[Eq. 7]

Growth $\left(\mathrm{g}_{\mathrm{r}}\right)$ and maintenance $\left(\mathrm{m}_{\mathrm{r}}\right)$ respiration coefficients can be estimated from the specific respiration rate $\left(\mathrm{R}_{\text {spec }}, \mathrm{g}\right.$ of $\mathrm{CH}_{2} \mathrm{O}$ per g of dry mass per day) and RGR (Hesketh et al., 1971): $\mathrm{R}_{\text {spec }}=\mathrm{R}_{\mathrm{CH} 2 \mathrm{O}} / \mathrm{DW}_{\text {crop }}=\mathrm{m}_{\mathrm{r}}+\mathrm{g}_{\mathrm{r}} \times \mathrm{RGR}$

[Eq. 8a]

This equation was modified for potential DLI effects on $g_{r}$ and $m_{r}$ :
$\mathrm{R}_{\text {spec }}=\mathrm{a}_{0}+\mathrm{a}_{1} \times \mathrm{DLI}+\left(\mathrm{b}_{0}+\mathrm{b}_{1} \times \mathrm{DLI}\right) \times \mathrm{RGR}$

[Eq. 8b]

where $\mathrm{m}_{\mathrm{r}}=\mathrm{a}_{0}+\mathrm{a}_{1} \times$ DLI ( $\mathrm{g}$ of $\mathrm{CH}_{2} \mathrm{O}$ per $\mathrm{g}$ of dry mass per day) and $g_{r}=b_{0}+b_{1} \times$ DLI ( $g$ of $\mathrm{CH}_{2} \mathrm{O}$ per g of dry mass).

Growth and maintenance respiration rates ( $\mathrm{g}$ of $\mathrm{CH}_{2} \mathrm{O}$ per day) of plants were estimated as

$\mathrm{R}_{\mathrm{g}}=\mathrm{g}_{\mathrm{r}} \times \mathrm{GR}$

and

$\mathrm{R}_{\mathrm{m}}=\mathrm{m}_{\mathrm{r}} \times \mathrm{DW}_{\text {day }}$

To determine the relationship between CUE and RGR or $\mathrm{R}_{\mathrm{g}} /$ $\mathrm{R}_{\mathrm{CH} 2 \mathrm{O}}$, we fitted rectangular hyperbolas $[\mathrm{CUE}=\mathrm{x} /(\mathrm{a} \times \mathrm{x}+\mathrm{b})$ ], since van Iersel (2003) has shown that

$1 / \mathrm{CUE}=1+\mathrm{g}_{\mathrm{r}}+\mathrm{m}_{\mathrm{r}} / \mathrm{RGR}$

[Eq. 11a]

which can be rearranged as

$\mathrm{CUE}=\mathrm{RGR} /\left[\left(1+\mathrm{g}_{\mathrm{r}}\right) \times \mathrm{RGR}+\mathrm{m}_{\mathrm{r}}\right] \quad$ [Eq. 11b]

where $\mathrm{g}_{\mathrm{r}}$ is in units of moles of $\mathrm{C}$ respired per mol of $\mathrm{C}$ incorporated into the plants, and $\mathrm{m}_{\mathrm{r}}$ is in mol of $\mathrm{C}$ respired per mol of $\mathrm{C}$ in the plants per day.

Final measurements. At harvest (25 d after transplanting), leaf chlorophyll concentration, leaf area, and shoot dry weight of 23 plants were determined. The remaining 12 plants were left in the gas exchange chambers for an additional day (for light response curves; Nemali, 2002), after which their root and shoot dry weights were determined. Leaf chlorophyll concentration (of 4 leaves from separate plants) was assessed using a chlorophyll meter (SPAD-502; Minolta Co., Japan) and leaf areas were measured using a leaf area meter (LI-3100; LI-COR). Total leaf area was estimated from the leaf area of the measured 23 plants. Root dry weight of the harvested 23 plants was estimated as the product of shoot dry weight of 23 plants and root to shoot ratio measured for the remaining 12 plants Leaf area ratio (LAR) was estimated as the ratio of leaf area to $\mathrm{DW}_{\mathrm{CROP}}$.

EXPERIMENTAL DESIGN AND DATA ANALYSIS. The experimental layout was a randomized complete block with two replications. Each experimental block (growth chamber) consisted of four DLI treatments (four gas exchange chambers), and each experimental unit (each gas exchange chamber) consisted of 35 plants. The effects of DLI on CER and other calculated variables were tested separately for each measurement day with linear and quadratic regression analysis. Other relationships among response variables were analyzed with both linear and nonlinear regressions, with $P<0.05$ considered to be statistically significant.

\section{Results and Discussion}

Plant Growth-DLI Relationships. At harvest, $\mathrm{DW}_{\mathrm{CROP}}$ and leaf area increased linearly, while leaf chlorophyll concentration decreased linearly with increasing DLI (Table 2). Leaf area ratio and shoot to root ratio were not affected by DLI. Increases in LAR with decreasing DLI have been reported in tall fescue (Allard et al., 1991) and dracaena (Vladimirova et al., 1997). To capture more light, plants grown in shade tend to develop larger and thinner leaves than those grown in full sunlight (Allard et al., 1991; Weibel et al., 1994). Since neither shoot-root ratio nor LAR was affected, wax begonia did not preferentially allocate a larger fraction of the available carbohydrates to leaf area production in response to a decrease in DLI from 19.4 to $5.3 \mathrm{~mol} \cdot \mathrm{m}^{-2} \cdot \mathrm{d}^{-1}$. Thus, the increase in leaf area with increasing DLI was simply the result of increased plant dry mass. High levels of total chlorophyll, and low chlorophyll $a$ to chlorophyll $b$ ratios, previously have been reported in response to shading (Adams and Demmig-Adams, 1992; Close et al., 2001), and may help plants maximize light interception under low DLI. 
Table 2. Effect of daily light integral (DLI) on leaf chlorophyll concentration, shoot and root dry weight (DW), leaf area ratio, and shoot-root ratio of subirrigated wax begonia. Data are the total of 35 plants. Statistical significance was tested using linear and quadratic regression and the quadratic component was found to be nonsignificant in all cases $\left(\mathrm{DLI}_{\text {coef }}=\right.$ coefficient for linear effect of DLI).

\begin{tabular}{|c|c|c|c|c|c|c|c|}
\hline $\begin{array}{l}\text { DLI } \\
\left(\mathrm{mol} \cdot \mathrm{m}^{-2} \cdot \mathrm{d}^{-1}\right)\end{array}$ & $\begin{array}{l}\text { Chlorophyll concn } \\
\text { (spad units) }\end{array}$ & $\begin{array}{c}\text { Leaf area } \\
\left(\mathrm{m}^{2}\right)\end{array}$ & $\begin{array}{l}\mathrm{DW}_{\text {CROP }} \\
(\mathrm{g})\end{array}$ & $\begin{array}{l}\mathrm{DW}_{\text {SноОт }} \\
(\mathrm{g})\end{array}$ & $\begin{array}{c}\mathrm{DW}_{\text {RоOT }} \\
(\mathrm{g})\end{array}$ & $\begin{array}{c}\text { Leaf area ratio } \\
\left(\mathrm{m}^{2} \cdot \mathrm{kg}^{-1}\right)\end{array}$ & $\begin{array}{l}\text { Shoot to root } \\
\text { ratio }\end{array}$ \\
\hline 5.3 & 30.3 & 0.8 & 23.9 & 16.4 & 7.6 & 31.5 & 2.2 \\
\hline 9.5 & 29.3 & 1.1 & 30.5 & 19.8 & 10.7 & 36.1 & 1.9 \\
\hline 14.4 & 29.2 & 1.3 & 36.3 & 26.3 & 10.1 & 35.8 & 2.6 \\
\hline 19.4 & 28.5 & 1.4 & 38.4 & 27.2 & 11.2 & 37.5 & 2.4 \\
\hline$r$ & -0.84 & 0.89 & 0.94 & 0.94 & --- & --- & --- \\
\hline intercept & $30.6^{* * * *}$ & $0.58^{* *}$ & $19.4^{* * * *}$ & $12.2^{* * * *}$ & 9.9 & 35.2 & 2.3 \\
\hline $\operatorname{DLI}_{\text {coef }}$ & $-0.11^{*}$ & $0.05^{* *}$ & $1.07^{* * * *}$ & $0.85^{* * *}$ & NS & NS & NS \\
\hline
\end{tabular}

Ns,*,*****Nonsignificant or significant at $P<0.05$, or 0.005 , or 0.0005 , respectively.

DaILY Light INTEGRAL AND $\mathrm{CO}_{2}$ EXCHANGE RATES. There was a strong correlation between $\mathrm{DW}_{\text {crop }}$ and CCG $(r=0.96)$, which indicates that gas exchange data were a realistic measure of crop growth (Fig. 1). Crop dry weight increased by $21.4 \mathrm{~g}$ for every mole of $\mathrm{C}$ incorporated by the plants. Carbon content in the plants $\left(f_{c}\right)$ was estimated from the slope of the regression line as 0.56 $\mathrm{g} \cdot \mathrm{g}^{-1}\left(12 \mathrm{~g} \cdot \mathrm{mol}^{-1} / 21.4 \mathrm{~g} \cdot \mathrm{mol}^{-1}\right)$. The estimated $\mathrm{C}$ content in wax begonia was higher than most other reported values, $0.465 \mathrm{~g} \cdot \mathrm{g}^{-1}$ for pansy [(Viola $\times$ wittrockiana Gams.) (van Iersel and Kang,

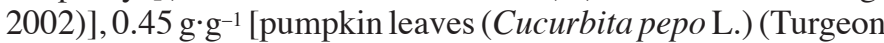
and Webb, 1975)], $0.396 \mathrm{~g} \cdot \mathrm{g}^{-1}$ [white clover (Trifolium repens L.) (McCree and Troughton, 1966a)], and $0.421 \mathrm{~g} \cdot \mathrm{g}^{-1}$ [sugar beet leaves (Beta vulgaris L.) (Terry and Mortimer, 2002)].

As expected, $\mathrm{C}$ fixation of the plants was closely related to DLI. There was a quadratic relationship between CCG and DLI (Fig. 2, top). The intercept of the regression line with the $\mathrm{x}$-axis $\left(125 \mathrm{~mol} \cdot \mathrm{m}^{-2}\right.$, equivalent to $5.0 \mathrm{~mol} \cdot \mathrm{m}^{-2} \cdot \mathrm{d}^{-1}$, or $100 \mu \mathrm{mol} \cdot \mathrm{m}^{-2} \cdot \mathrm{s}^{-1}$ with a 14-h photoperiod) is the estimated DLI at which there would have been no net gain of $\mathrm{C}$, i.e., the functional light compensation point. The functional light compensation point is higher than the light compensation point determined from $P P F$

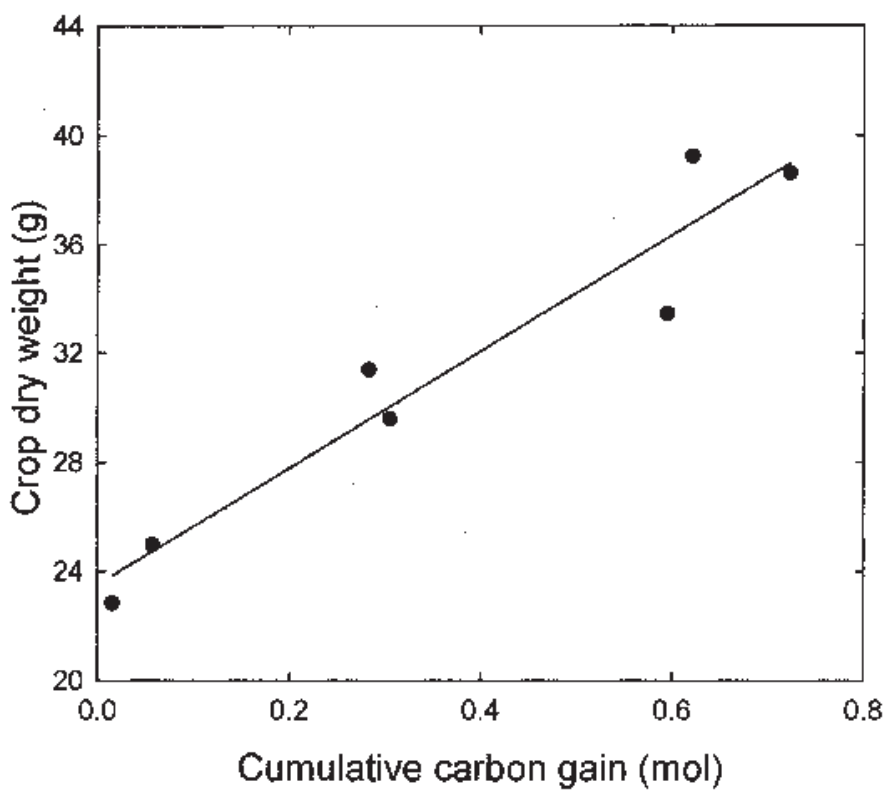

Fig. 1. Correlation between crop dry weight $\left(\mathrm{DW}_{\text {crop }}\right)$ and cumulative carbon gain (CCG) of wax begonia at the end of the experiment. Data represent the means of 35 plants in each experimental unit. Due to loss of data from one experimental unit only seven data points are shown; $\mathrm{DW}_{\text {crop }}=23.5+21.4 \times$ CCG $(r=0.96)$. response curves, which was $22 \mu \mathrm{mol} \cdot \mathrm{m}^{-2} \cdot \mathrm{s}^{-1}$ for these plants (Nemali, 2002). Note that the light compensation point as determined from photosynthesis $-P P F$ response curves is an indication of the
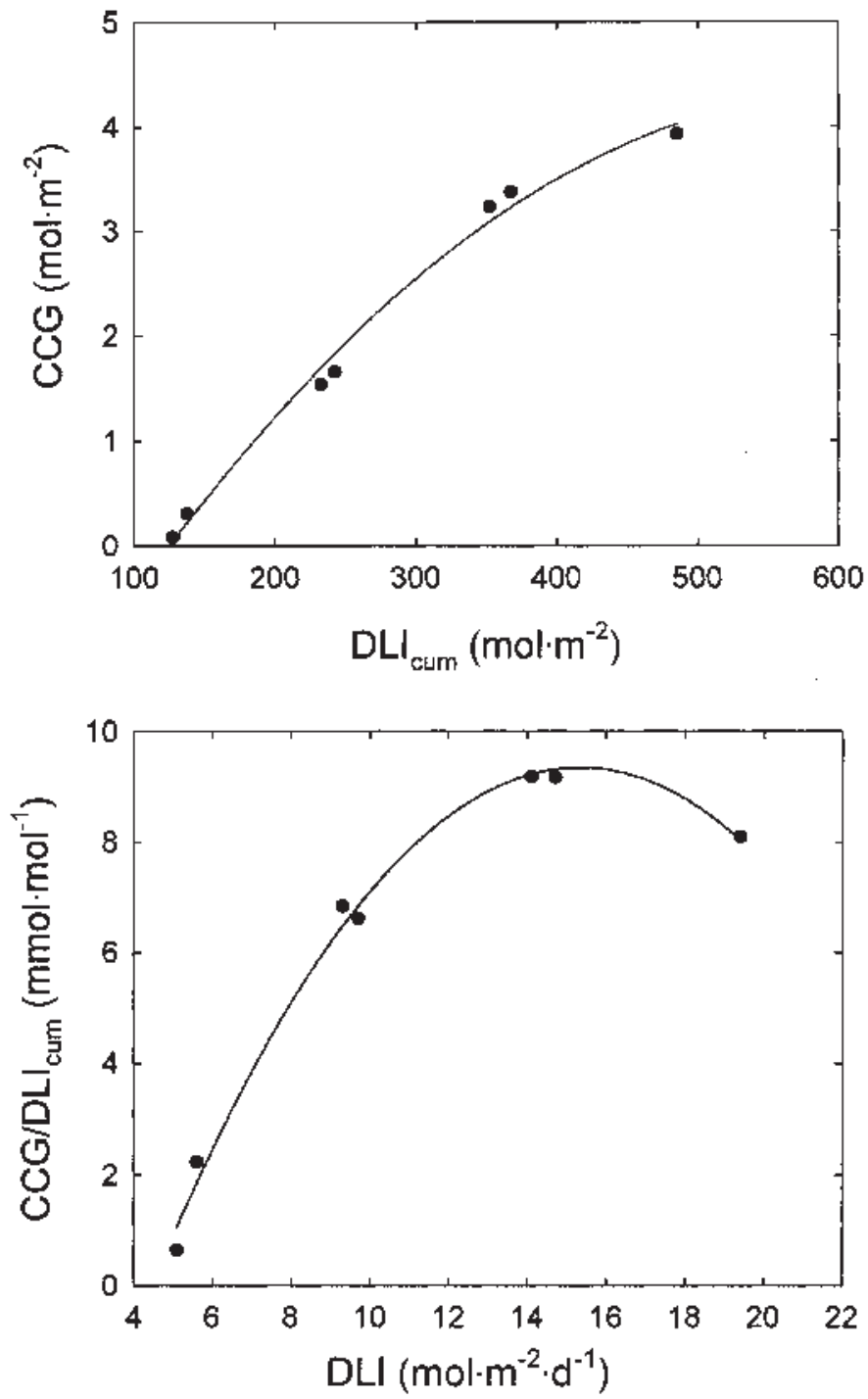

Fig. 2. Cumulative carbon gain (CCG) as a function of cumulative incident daily light integral (DLI $\left.\mathrm{cum}_{\mathrm{c}}\right)$ during the entire experiment (top), and CCG/DLI $\mathrm{cum}_{\text {, a }}$ measure of the efficiency with which incident $P P F$ was used to incorporate $\mathrm{C}$, as a function of DLI (bottom). The x-intercept of the regression lines is an estimate of the DLI at which CCG would have been zero (i.e., no growth). CCG $=-2.49+0.0222 \times \mathrm{DLI}_{\mathrm{cum}}-1.8 \times 10^{-5} \times \mathrm{DLI}_{\mathrm{cum}}{ }^{2}\left(r^{2}=0.99\right)$ and CCG/DLI ${ }_{\text {cum }}=$ $-9.25+2.43 \times \mathrm{DLI}-0.079 \times \mathrm{DLI}^{2}\left(r^{2}=0.99\right)$. 
$P P F$ at which $\mathrm{P}_{\mathrm{n}}$ is zero. Plants grown at a $P P F$ level at which $P_{n}$ is zero would have a negative DCG, since there would be no net $\mathrm{C}$ exchange during the light period and a $\mathrm{C}$ loss during the dark period. Plants grown at the functional light compensation point would have a net $\mathrm{C}$ gain during the light period that equals the $\mathrm{C}$ loss in the dark.

There was a quadratic relationship between $\mathrm{CCG} / \mathrm{DLI}_{\text {cum }}$ and DLI (Fig. 2 bottom). The ratio of CCG to DLI $_{\text {cum }}$ is a measure of the efficiency with which plants used the incident light to incorporate $\mathrm{C}$. This efficiency was very low $\left(\approx 0.93 \mathrm{mmol} \cdot \mathrm{mol}^{-1}\right)$ at $5 \mathrm{~mol} \cdot \mathrm{m}^{-2} \cdot \mathrm{d}^{-1}$, reached a maximum of $9.43 \mathrm{mmol} \cdot \mathrm{mol}^{-1}$ at 15.6 $\mathrm{mol} \cdot \mathrm{m}^{-2} \cdot \mathrm{d}^{-1}$, and decreased again slightly at higher DLIs. Treatment effects on CCG/DLI ${ }_{\text {cum }}$ can be due to differences in light absorption, $\mathrm{P}_{\mathrm{g}}$ per unit absorbed $P P F$, and the conversion of photosynthates into structural dry matter (CUE). The low ratio of CCG to $\mathrm{DLI}_{\text {cum }}$ at low light intensity was due at least partly to low light interception, since leaf area increased linearly with increasing DLI (Table 2). In addition, CUE increased with increasing DLI (see below), while $\mathrm{P}_{\mathrm{g}}$ per unit absorbed $P P F$ could not be

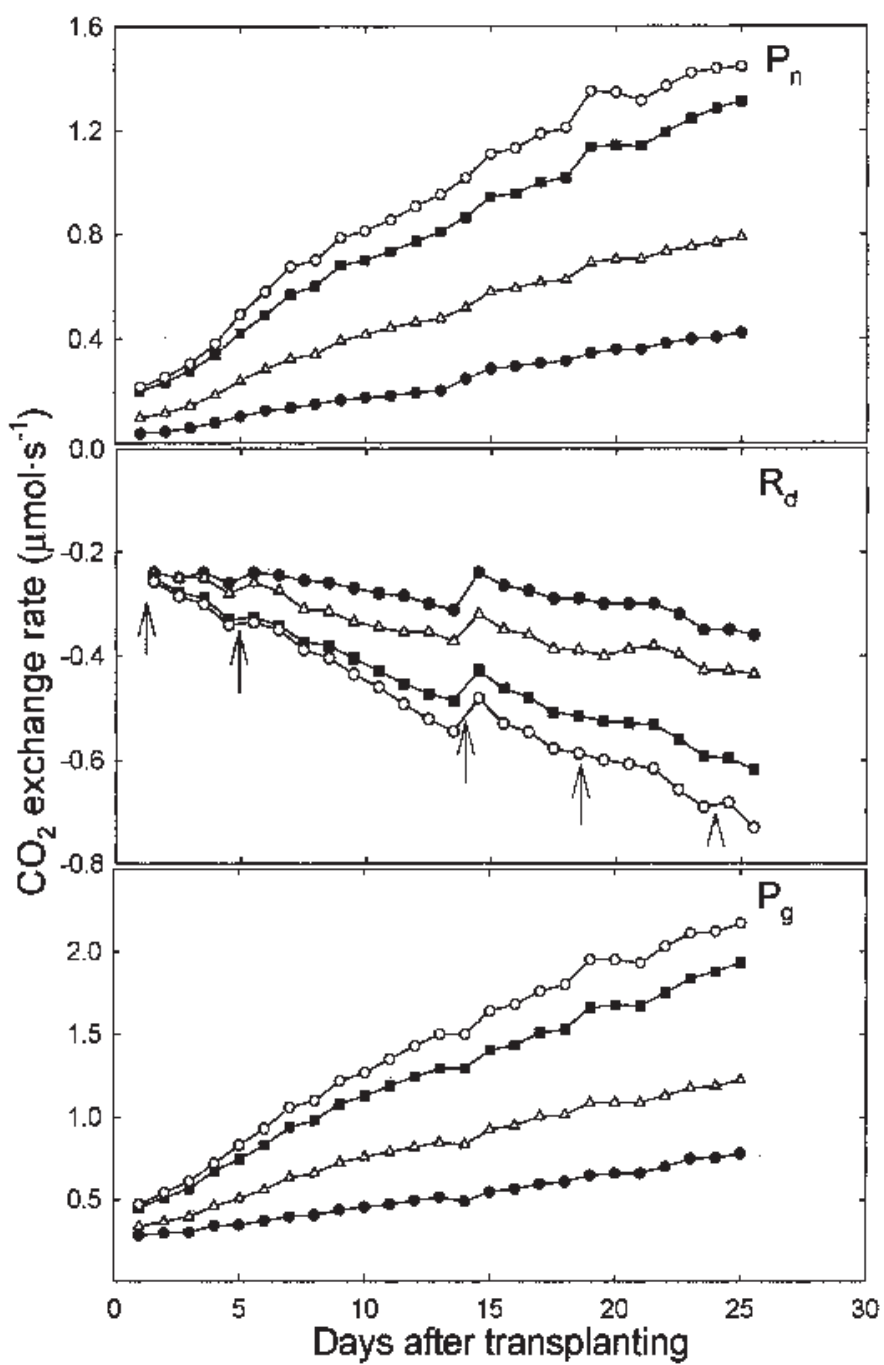

Fig. 3. Effect of photosynthetic photon flux on daily average net photosynthesis $\left(\mathrm{P}_{\mathrm{n}}\right)$, dark respiration $\left(\mathrm{R}_{\mathrm{d}}\right)$, and gross photosynthesis $\left(\mathrm{P}_{\mathrm{g}}\right)$ of subirrigated wax begonias during a period of $25 \mathrm{~d}$. Symbols $\mathbf{0}, \Delta, \boldsymbol{\square}$, and $O$ represent DLI levels at $5.3,9.5,14.4$, and $19.4 \mathrm{~mol} \cdot \mathrm{m}^{-2} \cdot \mathrm{d}^{-1}$, respectively. Data represent groups of 35 plants, averaged over two replications. Arrows indicate the time that plants were irrigated. All three parameters increased linearly with increasing DLI throughout the experiment. determined, since only incident, not absorbed, $P P F$ was measured. However, the photosynthetic efficiency of leaves (carbon fixed per unit absorbed $P P F$ ) decreases, when photosynthesis becomes light saturated (Jones, 1992). This can explain the decrease in $\mathrm{CCG} / \mathrm{DLI}_{\text {cum }}$ when DLI was greater than $15.2 \mathrm{~mol} \cdot \mathrm{m}^{-2} \cdot \mathrm{d}^{-1}$. As in Fig. 2 top, the $\mathrm{x}$-intercept in Fig. 2 bottom $\left(4.5 \mathrm{~mol} \cdot \mathrm{m}^{-2} \cdot \mathrm{d}^{-1}\right.$ or 88 $\mu \mathrm{mol} \cdot \mathrm{m}^{-2} \cdot \mathrm{s}^{-1}$ with 14 -h photoperiod) is an estimate of the functional light compensation point. The small difference between the two estimated functional light compensation points can be attributed to error in the data points used for the regressions.

Gross photosynthesis, $\mathrm{P}_{\mathrm{n}}$, and $\mathrm{R}_{\mathrm{d}}$ of the plants increased linearly with increasing DLI and increased steadily throughout the experiment (Fig. 3). This continuing increase in $\mathrm{CO}_{2}$ assimilation suggests that even near the end of the experiment, the plants did not use all incoming $P P F$ for $\mathrm{CO}_{2}$ assimilation, presumably due to an incomplete absorption of the incoming $P P F$. The continued increase in photosynthesis throughout the experiment is consistent

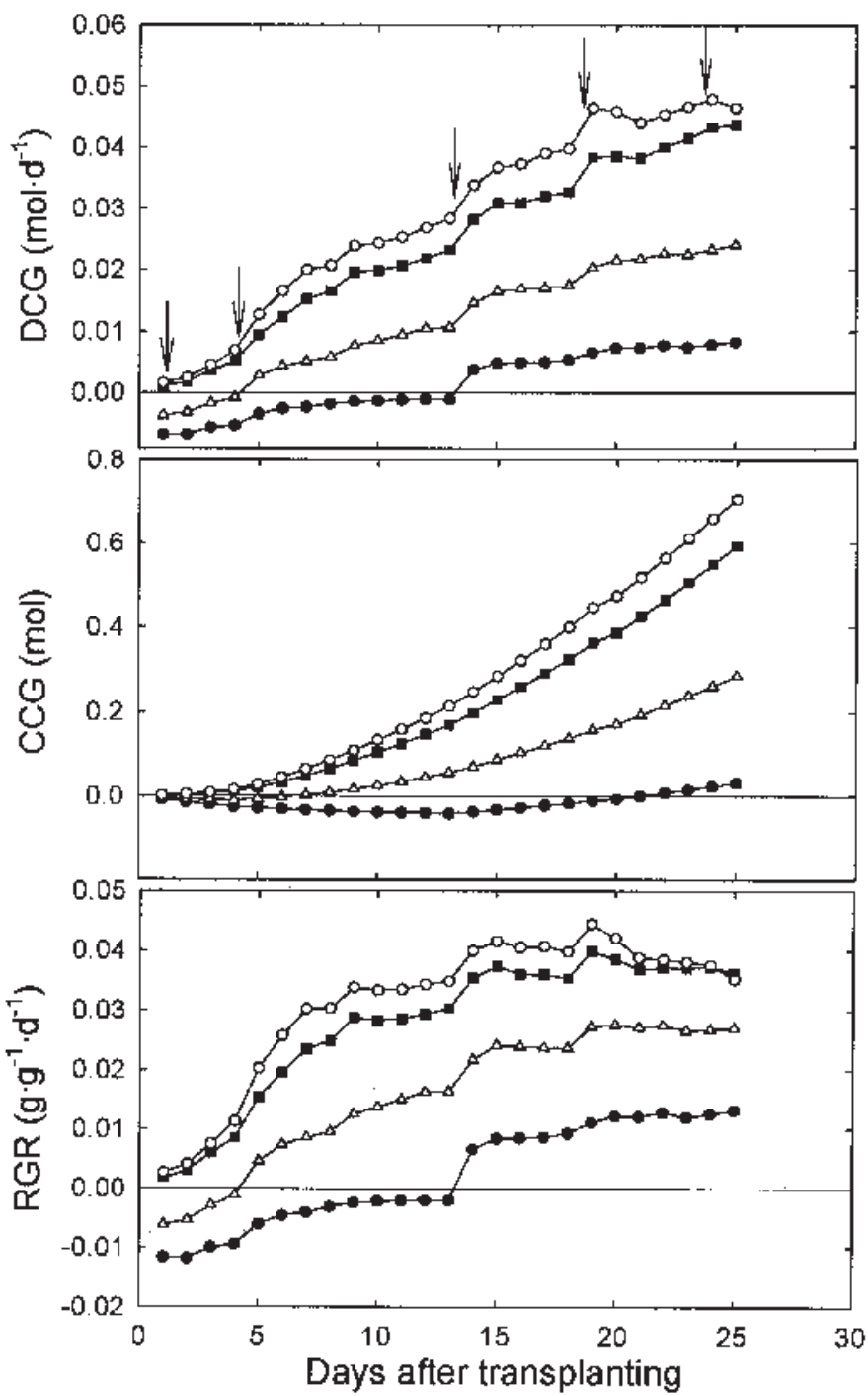

Fig. 4. Effect of photosynthetic photon flux on daily carbon gain(DCG), cumulative carbon gain (CCG) and relative growth rate (RGR) of subirrigated wax begonias during a period of $25 \mathrm{~d}$. Symbols $\boldsymbol{O}, \Delta, \mathbf{\square}$, and $\bigcirc$ represent DLI levels at 5.3, $9.5,14.4$, and $19.4 \mathrm{~mol} \cdot \mathrm{m}^{-2} \cdot \mathrm{d}^{-1}$, respectively. Data represent groups of 35 plants, averaged over two replications. Both DCG and CCG increased linearly and RGR of plants responded quadratically with increasing DLI during most of the growth period; however quadratic correlations in DCG and CCG were seen on days before watering plants (indicated by arrows). 


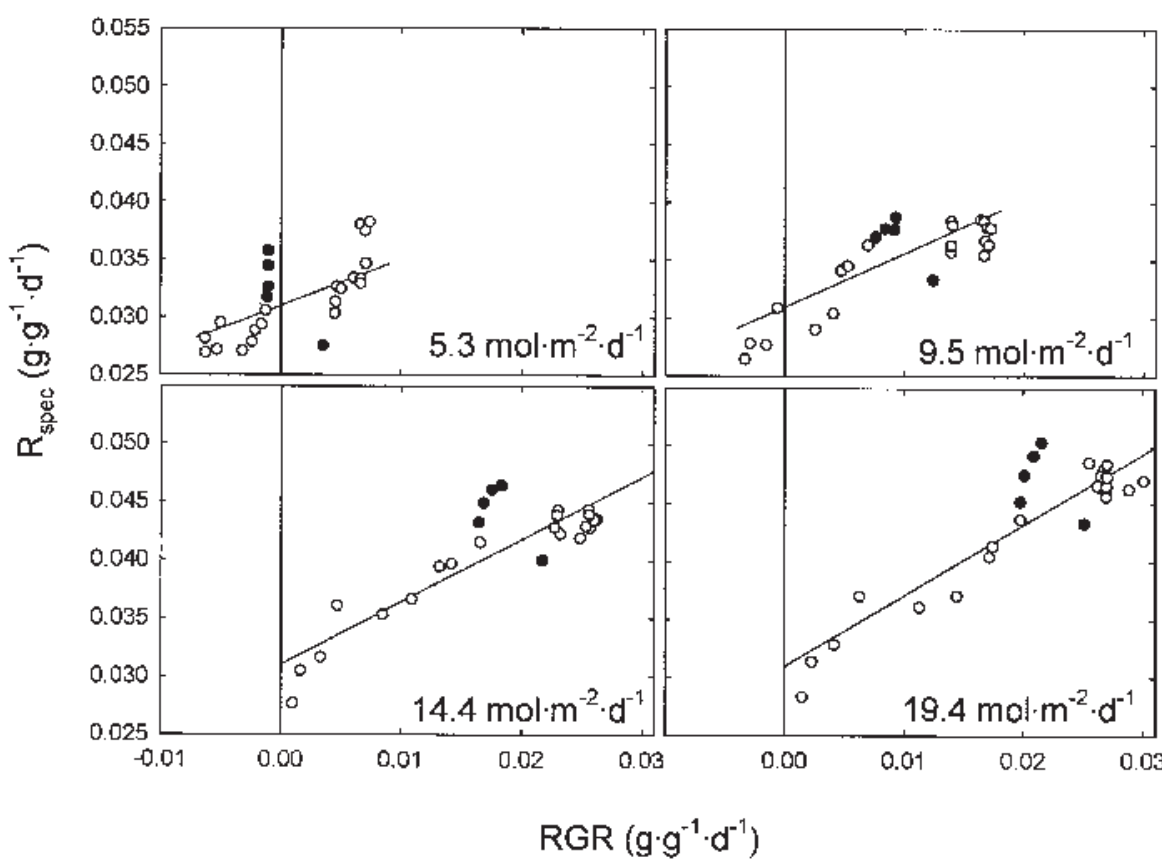

Fig. 5. Specific respiration rate $\left(\mathrm{R}_{\text {spec }}\right)$ as a function of relative growth rate (RGR) of wax begonia at different DLI levels. Lines indicate the regression results of a linear function, fitted to the combined data from all four light levels [Eq. $\left.8 \mathrm{~b}, \mathrm{R}_{\mathrm{CH} 2 \mathrm{O}} / \mathrm{DW}_{\text {crop }}=0.031+(0.324+0.015 \times \mathrm{DLI}) \times \mathrm{RGR}, R^{2}=0.81\right]$. Ignoring data points from day 10 to 14 (closed symbols), when drought and rewatering greatly reflected respiration rates, improved the fit, but had little effect on the regression parameters $\left[\mathrm{R}_{\mathrm{CH} 2 \mathrm{O}} / \mathrm{DW}_{\text {crop }}=0.030+(0.381+0.011 \times \mathrm{DLI}) \times \mathrm{RGR}\right.$, $\left.R^{2}=0.88\right]$.

with the finding that the growth of white clover keeps increasing with increasing leaf area index (McCree and Troughton, 1966b). The leaf area index of wax begonias grown at $19.4 \mathrm{~mol} \cdot \mathrm{m}^{-2} \cdot \mathrm{d}^{-1}$ was 8.8 at the end of the experiment.

Although $\mathrm{R}_{\mathrm{d}}$ in all treatments generally increased throughout the experiment, there was a distinct decrease in $R_{d}$ after plants were watered on day 13 . This was accompanied by an increase in DCG (Fig. 4), which indicates that growth of the plants was limited by a mild drought stress prior to this irrigation. There were no visible symptoms of drought (e.g., wilting) at any time.

Negative DCG values (i.e., net carbon losses) were seen during the initial 13 and $4 \mathrm{~d}$ for plants grown at a DLI of 5.3 and 9.5 $\mathrm{mol} \cdot \mathrm{m}^{-2} \cdot \mathrm{d}^{-1}$, respectively (Fig. 4). This may be partly due to microbial breakdown of the organic matter in the growing medium, which increases total respiration, and thus decreases DCG. However, even under a high DLI of 21.4 $\mathrm{mol} \cdot \mathrm{m}^{-2} \cdot \mathrm{d}^{-1}$, negative DCG values were reported after transplanting vinca (Catharanthus roseus L.) (van Iersel, 1999) into an inorganic growing medium, where microbial breakdown of organic components of the growing medium did not affect the measurements. This indicates that plants can respire more carbohydrates than are synthesized in photosynthesis soon after transplanting (possibly from storage forms like starch). This may be related to the need to repair damage caused by transplanting.

Since CCG is DCG integrated over time, treatment effects on DCG resulted in differences in CCG as well. Thus, plants grown at 5.3 and $9.5 \mathrm{~mol} \cdot \mathrm{m}^{-2} \cdot \mathrm{d}^{-1}$ had a negative CCG during the initial 20 and $6 \mathrm{~d}$ of crop growth, respectively (Fig. 4). Both DCG and CCG were positively correlated with DLI throughout the experiment $(P<0.05)$, which would be expected based on $P P F$ effects on photosynthesis (Fig. 2).

Relative growth rate increased linearly with DLI until day 10, and from day 10 onwards, quadratic responses of RGR to DLI were seen (Fig. 4). There was a large increase in RGR with an increase in DLI from 5.3 to 14.4 $\mathrm{mol} \cdot \mathrm{m}^{-2} \cdot \mathrm{d}^{-1}$, followed by only a small or no increase in RGR as DLI increased from 14.4 to $19.4 \mathrm{~mol} \cdot \mathrm{m}^{-2} \cdot \mathrm{d}^{-1}$. From day 21 onwards, RGR was similar for plants grown at 14.4 and 19.4 $\mathrm{mol} \cdot \mathrm{m}^{-2} \cdot \mathrm{d}^{-1}$ (Fig. 4). Somewhat surprisingly, RGR of the plants increased throughout the first $18 \mathrm{~d}$, after which it remained fairly steady in all treatments. Normally, RGR decreases with increasing plant size because of increased intra- and inter-plant competition for light (Kvet et al., 1971). The low RGR during the early part of this experiment may be due to transplant shock and acclimation of the plants to the environmental conditions in the gas exchange chambers. At harvest, the RGR for plants grown at $5.3,9.5,14.4$, and $19.4 \mathrm{~mol} \cdot \mathrm{m}^{-2 \cdot} \mathrm{d}^{-1}$ was $0.013,0.027,0.036$, and $0.035 \mathrm{~g} \cdot \mathrm{g}^{-1} \cdot \mathrm{d}^{-1}$, respectively. Similar to DCG, RGR was negative during the initial 4 and $13 \mathrm{~d}$ for plants grown at 5.3 and $9.5 \mathrm{~mol} \cdot \mathrm{m}^{-2} \cdot \mathrm{d}^{-1}$. These estimated $\mathrm{RGR}$ values

Fig. 6. Estimated maintenance $\left(\mathrm{R}_{\mathrm{m}}\right)$ and growth $\left(\mathrm{R}_{\mathrm{g}}\right)$ respiration of subirrigated wax begonias shown as percentage of total respiration during $25 \mathrm{~d}$ of crop growth. Symbols $\bigcirc, \Delta, \mathbf{\square}$, and $\bigcirc$ represent DLI levels at 5.3, 9.5, 14.4, and $19.4 \mathrm{~mol} \cdot \mathrm{m}^{-2} \cdot \mathrm{d}^{-1}$, respectively. Data represent groups of 35 plants averaged over two replications. When the estimated $\mathrm{R}_{\mathrm{m}}$ exceeded total daily respiration, and estimated $\mathrm{R}_{\mathrm{g}}$ was negative, $\mathrm{R}_{\mathrm{m}}$ and $\mathrm{R}_{\mathrm{g}}$ were assumed to account for $100 \%$ and $0 \%$ of total respiration, respectively. There were linear effects of $D L I$ on the ratios of $\mathrm{R}_{\mathrm{g}}$ and $\mathrm{R}_{\mathrm{m}}$ to total respiration from 5 to $11 \mathrm{~d}$, and quadratic effects from 12 to $25 \mathrm{~d}$ after transplanting $(P<0.05)$.

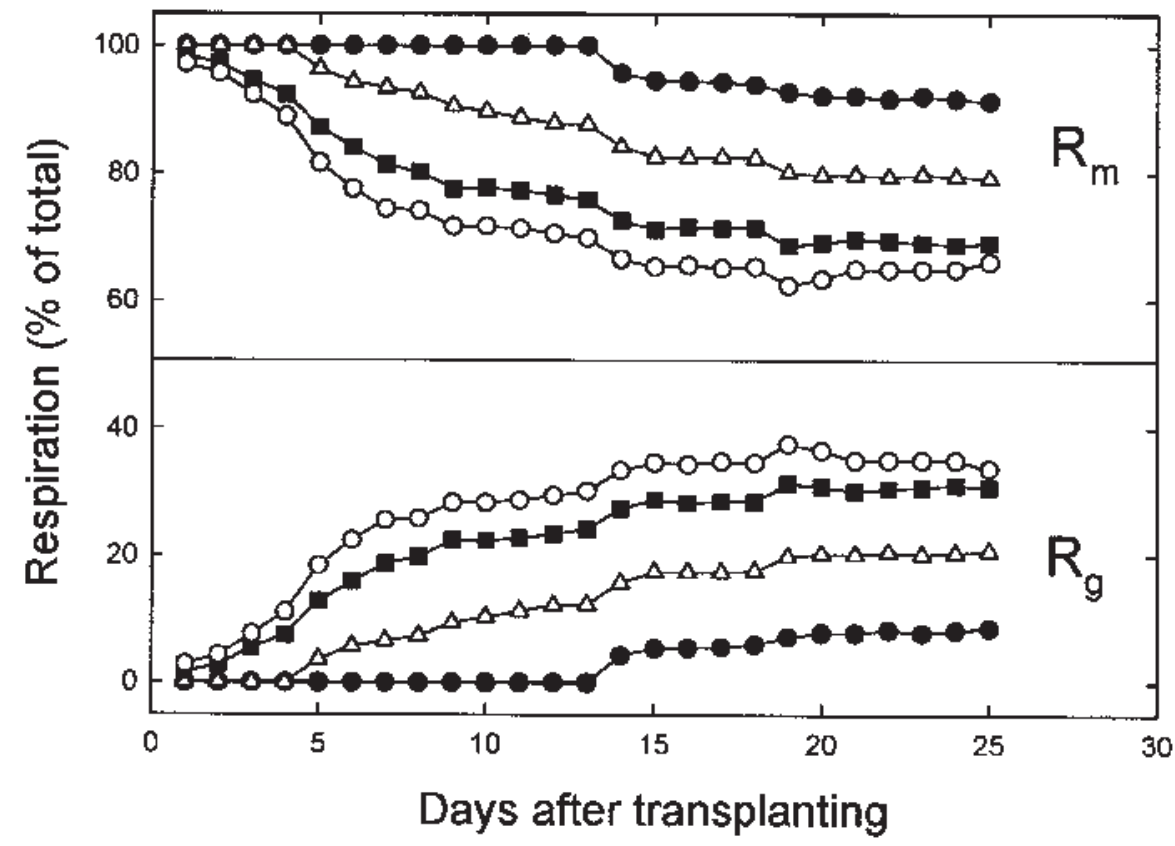



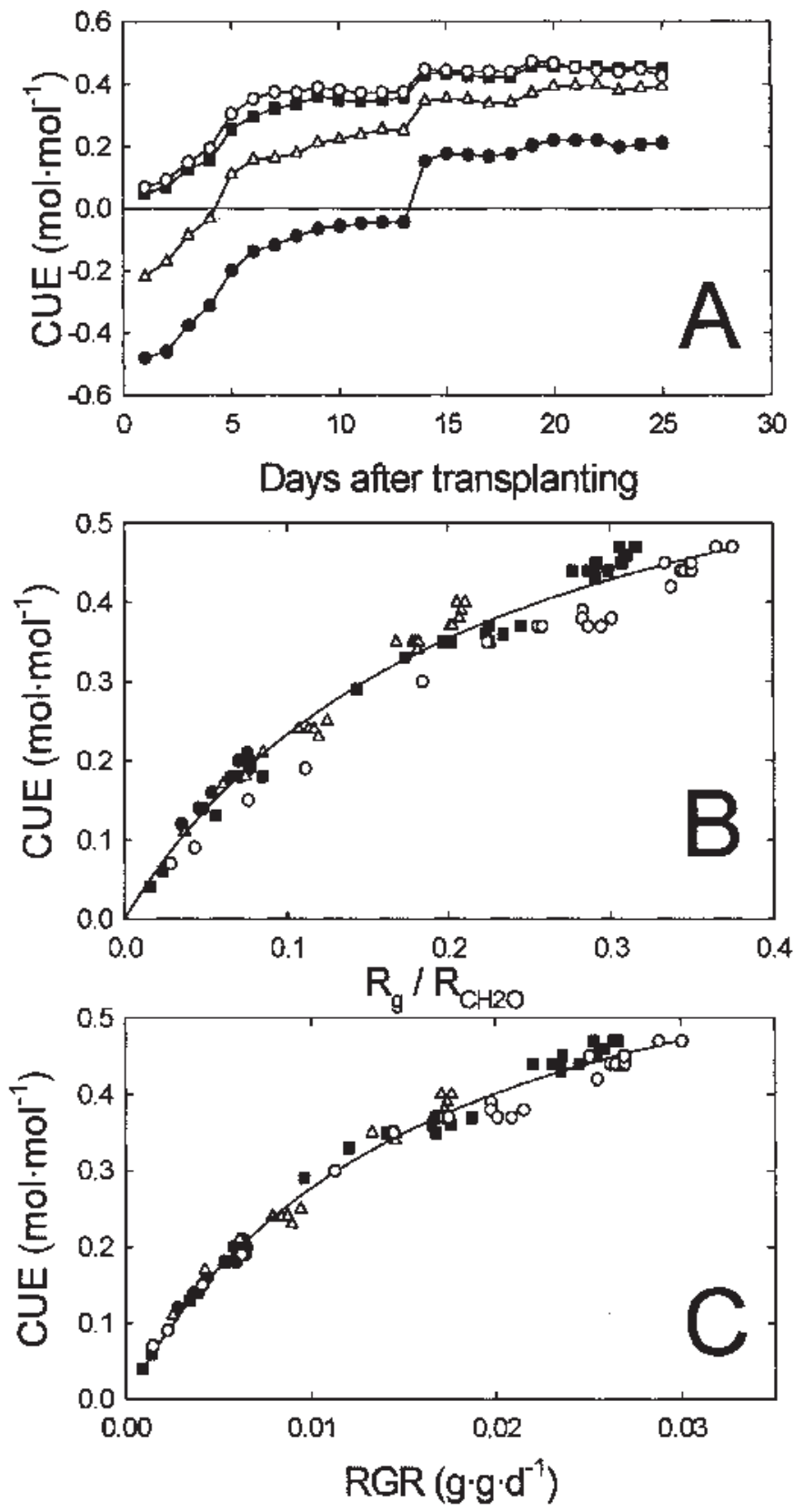

Fig. 7. Carbon use efficiency (CUE) as a function of (A) time, $(\mathbf{B})$ relative growth rate $(\mathrm{RGR})$, and $(\mathbf{C})$ growth respiration as a fraction of total respiration $\left(\mathrm{R}_{\mathrm{g}} /\right.$ $\mathrm{R}_{\mathrm{CH} 2 \mathrm{O}}$ ). Symbols $\bigcirc, \Delta, \boldsymbol{\square}$, and $\bigcirc$ represent DLI levels at 5.3, 9.5, 14.4, and 19.4 $\mathrm{mol} \cdot \mathrm{m}^{-2} \cdot \mathrm{d}^{-1}$, respectively. In $\mathbf{A}$, data represent groups of 35 plants averaged over two replications. For $\mathbf{B}$ and $\mathbf{C}$, only positive CUE values are included, and data points represent individual experimental units. CUE $=[\mathrm{RGR} /(1.383$ $\times \mathrm{RGR}+0.0222)],\left(R^{2}=0.99\right)$ and $\mathrm{CUE}=\left[\left(\mathrm{R}_{\mathrm{g}} / \mathrm{R}_{\mathrm{CH} 2 \mathrm{O}}\right) /\left(1.26 \times \mathrm{R}_{\mathrm{g}} / \mathrm{R}_{\mathrm{CH} 2 \mathrm{O}}\right)+\right.$ $0.294],\left(R^{2}=0.96\right)$.

are lower than those previously reported for wax begonia $(0.05$ to $0.09 \mathrm{~g} \cdot \mathrm{g}^{-1 \cdot} \cdot \mathrm{d}^{-1}$, Kessler and Armitage, 1992), salvia [Salvia splendens F. Sellow ex Roem. \& Schult. $\left(0.15\right.$ to $\left.0.2 \mathrm{~g} \cdot \mathrm{g}^{-1} \cdot \mathrm{d}^{-1}\right)$, van Iersel, 1997], and impatiens [Impatiens parviflora D.C. (0.2 to $\left.0.25 \mathrm{~g} \cdot \mathrm{g}^{-1} \cdot \mathrm{d}^{-1}\right)$, Peace and Grubb, 1982]. However, growing conditions, especially DLI, varied between our experiment and the other studies, which likely affected RGR.

GrowTH AND MAINTENANCE RESPIRATION. An increase in DLI increased $g_{r}$, but had no significant effect on $\mathrm{m}_{\mathrm{r}}\left(\right.$ Fig. $5, \mathrm{R}_{\mathrm{CH} 2 \mathrm{O} /} \mathrm{DW}_{\text {crop }}$ $\left.=0.031+(0.322+0.015 \times \mathrm{DLI}) \times \mathrm{RGR}, R^{2}=0.81\right)$. Based on this equation, the estimated $\mathrm{m}_{\mathrm{r}}$ for plants was $0.031 \mathrm{~g} \cdot \mathrm{g}^{-1} \cdot \mathrm{d}^{-1}$ and $\mathrm{g}_{\mathrm{r}}$ for plants grown at $5.3,9.5,14.4$, and $19.4 \mathrm{~mol} \cdot \mathrm{m}^{-2} \cdot \mathrm{d}^{-1}$ were $0.40,0.47,0.54$, and $0.62 \mathrm{~g} \cdot \mathrm{g}^{-1}$, respectively. An earlier study on white clover (McCree,1982) grown initially at high PPF (1750

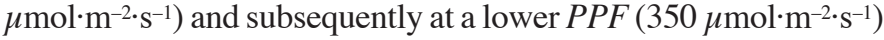
indicated that $g_{\mathrm{r}}$ remained constant and $\mathrm{m}_{\mathrm{r}}$ decreased from 65 to 39 $\mathrm{mg} \cdot \mathrm{g}^{-1} \cdot \mathrm{d}^{-1}$ when plants were shifted from high to low irradiance. In contrast to that experiment, plants in our study were grown at lower, constant DLI levels and probably better adapted to low DLI due to the shade tolerance of wax begonia.

Literature values for $\mathrm{m}_{\mathrm{r}}$ differ widely. In their review, Hesketh and Jones (1980) reported $\mathrm{m}_{\mathrm{r}}$ values for many species ranging from 6 to $91 \mathrm{mg} \cdot \mathrm{g}^{-1} \cdot \mathrm{d}^{-1}$, while Amthor (2000) states that $\mathrm{m}_{\mathrm{r}}$ falls in the range of 3.3 to $138 \mathrm{mg} \cdot \mathrm{g}^{-1} \cdot \mathrm{d}^{-1}$. The estimated $\mathrm{m}_{\mathrm{r}}$ of wax begonia $\left(31 \mathrm{mg} \cdot \mathrm{g}^{-1} \cdot \mathrm{d}^{-1}\right)$ is well within these ranges, and similar to that of italian ryegrass tops [Lolium multiflorum L. $\left(37 \mathrm{mg} \cdot \mathrm{g}^{-1} \cdot \mathrm{d}^{-1}\right)$ ], higher than that of chrysanthemum [Chrysanthemum morifolium L. (17 $\left.\mathrm{mg} \cdot \mathrm{g}^{-1} \cdot \mathrm{d}^{-1}\right)$ ], perennial ryegrass [Lolium perenne $\mathrm{L} .\left(14 \mathrm{mg} \cdot \mathrm{g}^{-1} \cdot \mathrm{d}^{-1}\right)$ ], and tomato [Lycopersiconesculentum $\mathrm{L} .\left(12 \mathrm{mg} \cdot \mathrm{g}^{-1} \cdot \mathrm{d}^{-1}\right)$ ], but lower than that of roots of italian ryegrass $\left(91 \mathrm{mg} \cdot \mathrm{g}^{-1} \cdot \mathrm{d}^{-1}\right)($ Hesketh and Jones, 1980).

Our $g_{\mathrm{r}}$ estimates $\left(0.40\right.$ to $\left.0.62 \mathrm{~g} \cdot \mathrm{g}^{-1}\right)$ were slightly higher than

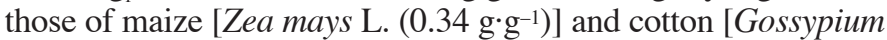
hirsutum L. (0.33 to $\left.0.39 \mathrm{~g} \cdot \mathrm{g}^{-1}\right)$, similar to that of chrysanthemum $\left(0.56 \mathrm{~g} \cdot \mathrm{g}^{-1}\right)$, and lower than that of roots of italian ryegrass $(0.67$ $\mathrm{g} \cdot \mathrm{g}^{-1}$ ) (reviewed by Hesketh and Jones, 1980). Experimental estimates from a variety of studies suggest that $\mathrm{g}_{\mathrm{r}}$ is similar (generally differing by $<10 \%$ ) among plant parts, species, and growing conditions (Cannell and Thornley, 2000), and normally close to $0.4 \mathrm{~g} \cdot \mathrm{g}^{-1}$. However, $\mathrm{g}_{\mathrm{r}}$ depends on which chemical compounds are synthesized by the plants (Penning de Vries et al., 1974), which in turn may depend on DLI. Plants grown under a high DLI generally have higher concentrations of photosynthetic enzymes (Hikosaka, 1996), and the production of enzymes requires a relatively much energy (Penning de Vries et al., 1974). Therefore, an increase in DLI is likely to result in an increase in $\mathrm{g}_{\mathrm{r}}$ as well.

Since $R_{g}$ and $R_{m}$ were calculated as $g_{r} \times G R$ and $m_{r} \times D W_{\text {crop }}$, respectively, trends in $R_{g}$ and $R_{m}$ were similar to those for DCG and CCG. Both $\mathrm{R}_{\mathrm{g}}$ and $\mathrm{R}_{\mathrm{m}}$ increased with increasing DLI throughout the experiment (results not shown). Throughout the entire experiment, and at all DLI levels, $R_{m}$ was greater than $R_{g}$ (Fig. 6). At the start of the experiment, $\mathrm{R}_{\mathrm{m}}$ accounted for almost all of $\mathrm{R}_{\mathrm{CH} 2 \mathrm{O}}(97$ to $100 \%$ ). At harvest, the percentage of $R_{m}$ was $91,79,69$, and $66 \%$ of $\mathrm{R}_{\mathrm{CH} 2 \mathrm{O}}$ for plants grown at $5.3,9.5,14.4$, and $19.4 \mathrm{~mol} \cdot \mathrm{m}^{-2} \cdot \mathrm{d}^{-1}$, respectively. The fraction of $\mathrm{R}_{\mathrm{CH} 2 \mathrm{O}}$ that was used for growth increased throughout most of the experiment and with increasing DLI (Fig. 6). Growth respiration accounted for a higher fraction of $\mathrm{R}_{\mathrm{CH} 2 \mathrm{O}}$ with increasing DLI because both DCG and $\mathrm{g}_{\mathrm{r}}$ increased with increasing DLI. Usually, $\mathrm{R}_{\mathrm{g}}$ accounts for most $(\approx 80 \%)$ of the total respiration during the vegetative stage, and decreases during the reproductive stage (to $\approx 20 \%$; Lawlor, 1995 ). The high ratio of $\mathrm{R}_{\mathrm{m}}$ to $\mathrm{R}_{\mathrm{CH} 2 \mathrm{O}}$ of wax begonia may be an indirect effect of the low photosynthetic rate of these plants. At light saturation, $P_{n}$ per unit leaf area of these plants ranged from $4.5 \mu \mathrm{mol} \cdot \mathrm{m}^{-2} \cdot \mathrm{s}^{-1}$ for plants grown at a DLI level of $5.3 \mathrm{~mol} \cdot \mathrm{m}^{-2} \cdot \mathrm{d}^{-1}$ to $8.1 \mu \mathrm{mol} \cdot \mathrm{m}^{-2} \cdot \mathrm{s}^{-1}$ for plants grown at $19.4 \mathrm{~mol} \cdot \mathrm{m}^{-2} \cdot \mathrm{d}^{-1}$ (Nemali, 2002), while typical maximum leaf $\mathrm{P}_{\mathrm{n}}$ rates of $\mathrm{C}_{3}$-plants range from 14 to $40 \mu \mathrm{mol} \cdot \mathrm{m}^{-2} \cdot \mathrm{s}^{-1}$ (Jones, 1992). Thus, wax begonias produce relatively low levels of carbohydrates, and most of these are used for $\mathrm{R}_{\mathrm{m}}$, leaving a small carbohydrate pool for growth and $\mathrm{R}_{\mathrm{g}}$. This also can explain the slow growth habit of wax begonias.

Carbonuse efficiency. At the lowestDLIlevel $\left(5.3 \mathrm{~mol} \cdot \mathrm{m}^{-2} \cdot \mathrm{d}^{-1}\right)$, 
CUE increased from -0.48 to $0.21 \mathrm{~mol} \cdot \mathrm{mol}^{-1}$ during the experiment, while CUE increased from 0.07 to $0.45 \mathrm{~mol} \cdot \mathrm{mol}^{-1}$ at a DLI level of $19.4 \mathrm{~mol} \cdot \mathrm{m}^{-2} \cdot \mathrm{d}^{-1}(\mathrm{Fig}$. 7A). Carbon use efficiency generally ranges from 0.5 to $0.7 \mathrm{~mol} \cdot \mathrm{mol}^{-1}$ (Bednarz and van Iersel, 1999; Gifford 1995). The low CUE of wax begonia can be explained from its low photosynthetic rate, and the large fraction of carbohydrates used for $\mathrm{R}_{\mathrm{m}}$ (Fig. 6).

Carbon use efficiency of plants responded quadratically to an increase in DLI. There was an increase in CUE from 5.3 to 14.4 $\mathrm{mol} \cdot \mathrm{m}^{-2} \cdot \mathrm{d}^{-1}$, while CUE was similar at 14.4 and $19.4 \mathrm{~mol} \cdot \mathrm{m}^{-2} \cdot \mathrm{d}^{-1}$ (Fig. 7A). There was a sudden increase in CUE after watering on day 14 , due to a decrease in $\mathrm{R}_{\mathrm{d}}$ and an increase in DCG (Figs. 3 and 4). In all DLI treatments, CUE increased during the first $14 \mathrm{~d}$ of the experiment. At the two lowest light levels, CUE was negative early in the experiment, a direct effect of the negative DCG as plants did not produce enough carbohydrates to meet maintenance requirements during the first 13 and $4 \mathrm{~d}$, respectively (Fig. 6). A negative DCG indicates that plants were catabolizing reserves or structural dry matter to meet the respiratory demand.

Although $\mathrm{CO}_{2}$ production from microbial breakdown of organic components of the growing medium is negligible compared to the metabolic activity of rapidly growing plants (van Iersel and Bugbee, 2000), it may be significant when the $\mathrm{CO}_{2}$ exchange rate of the plants is low. This would result in an underestimation of DCG, not affect $P_{g}$ estimates (unless microbial breakdown of the growing medium differs in the light and in darkness), and therefore result in an underestimation of CUE. This may have been a factor contributing to the low CUE of plants grown at low DLI during the early part of the growing period. However, previous work has shown that a negative CUE may occur after transplanting, even when there is no microbial breakdown of the growing medium. After vinca was transplanted into an inorganic growing medium, $R_{d}$ increased rapidly and CUE became negative (van Iersel, 1999).

There was a close relationship between CUE and the ratio of $\mathrm{R}_{\mathrm{g}}$ to $\mathrm{R}_{\mathrm{CH} 2 \mathrm{O}}\left(R^{2}=0.96\right)$ and between CUE and RGR $\left(R^{2}=0.99\right)$ (Fig. $7 \mathrm{~B}, \mathrm{C})$. The regression results from the hyperbolic relationship between CUE and RGR can be used to estimate $\mathrm{g}_{\mathrm{r}}$ and $\mathrm{m}_{\mathrm{r}}$. Based on Eq. $11 \mathrm{~b}$, estimates of $\mathrm{g}_{\mathrm{r}}$ and $\mathrm{m}_{\mathrm{r}}$ are $0.383 \mathrm{~mol} \cdot \mathrm{mol}^{-1}$ and 0.0222 $\mathrm{mol} \cdot \mathrm{mol}^{-1} \cdot \mathrm{d}^{-1}$, respectively. These estimates can be converted to $0.54 \mathrm{~g} \cdot \mathrm{g}^{-1}$ (grams of glucose per gram dry matter) for $\mathrm{g}_{\mathrm{r}}$ and 0.031 $\mathrm{g} \cdot \mathrm{g}^{-1} \cdot \mathrm{d}^{-1}$ for $\mathrm{m}_{\mathrm{r}}$, based on an $\mathrm{f}_{\mathrm{c}}$ of 0.56 for the plant material and 0.40 for glucose. Since data from all DLI treatments were combined in this regression analysis, these estimates ignore DLI effects on $g_{r}$, and thus represent an average for the different treatments. Nonetheless, the regression resulted in an excellent fit $\left(R^{2}=0.99\right)$, so apparently any differences in $\mathrm{g}_{\mathrm{r}}$ among DLI treatments had little or no effect on CUE. Presumably, this was the case because $\mathrm{R}_{\mathrm{g}}$ only accounted for a small fraction of total respiration (Fig. 6).

The asymptotes of the regressions of CUE versus the ratio of $\mathrm{R}_{\mathrm{g}}$ to $\mathrm{R}_{\mathrm{CH} 2 \mathrm{O}}\left(0.74 \mathrm{~mol} \cdot \mathrm{mol}^{-1}\right)$ and versus $\mathrm{RGR}\left(0.72 \mathrm{~mol} \cdot \mathrm{mol}^{-1}\right)(\mathrm{Fig}$. $7 \mathrm{~B}, \mathrm{C}$ ) are estimates of the theoretical maximum for CUE (i.e., CUE in the absence of any $R_{m}$ ) for wax begonia. These values are similar to estimated maximum CUEs of pansy $\left(0.67 \mathrm{~mol} \cdot \mathrm{mol}^{-1}\right.$; van Iersel and Kang, 2002) and lettuce (Lactuca sativa L.) (0.68 $\mathrm{mol} \cdot \mathrm{mol}^{-1}$; van Iersel, 2003). The actual CUE of the plants was much lower $(<0.5)$ than the theoretical maximum because a large fraction of photosynthates was used for maintenance.

\section{Conclusions}

Plants grown at 5.3 and $9.5 \mathrm{~mol} \cdot \mathrm{m}^{-2} \cdot \mathrm{d}^{-1}$ had a low growth rate due to inadequate incident DLI, insufficient light interception (at least partially due to small leaf areas), and low photosynthetic rates. Growth rate of plants increased with increasing DLI because both $\mathrm{P}_{\mathrm{g}}$ and CUE increased with increasing DLI. At the lower DLIs (5.3 and $\left.9.5 \mathrm{~mol} \cdot \mathrm{m}^{-2} \cdot \mathrm{d}^{-1}\right)$, photosynthesis initially was insufficient to meet maintenance requirements for carbohydrates, resulting in a negative DCG, RGR, and CUE. The importance of $R_{m}$ in the carbon balance, and thereby on the growth rate of the plants, decreased with increasing DLI. At low DLI, plants produce relatively few carbohydrates, and only a small fraction of this carbohydrate pool is available for growth after maintenance requirements are met. This explains the higher $\mathrm{R}_{\mathrm{m}} / \mathrm{R}_{\mathrm{CH} 2 \mathrm{O}}$ and lower growth rate of plants grown at 5.3 and $9.5 \mathrm{~mol} \cdot \mathrm{m}^{-2} \cdot \mathrm{d}^{-1}$. Wax begonia had lower CUE and RGR than most reported values for other crops. This too may be attributed to the low photosynthetic capacity of wax begonia. Although considered to be shade tolerant, growth of wax begonias is inhibited at DLI levels of $9.5 \mathrm{~mol} \cdot \mathrm{m}^{-2 \cdot} \cdot \mathrm{d}^{-1}$, which is considered a moderate amount of light inside a greenhouse. Growth and CUE of wax begonia were constrained because they had more $\mathrm{R}_{\mathrm{m}}$ than $\mathrm{R}_{\mathrm{g}}$. Photosynthetic rates were much lower than those of other $\mathrm{C}_{3}$ species even at the highest DLI. A future issue would be to identify the physiological reason for these low photosynthetic rates.

\section{Literature Cited}

Adams, W.W. III. and B. Demmig-Adams. 1992. Operation of xanthophyll cycle in higher plants in response to diurnal changes in incident sunlight. Planta 186:390-398.

Allard, G., C.J. Nelson, and S.G. Pallardy. 1991. Shade effects on growth of tall fescue: I. Leaf anatomy and dry matter partitioning. Crop Sci. 31:163-167.

Amthor, J.S. 1984. The role of maintenance respiration in plant growth. Plant Cell Environ. 7:561-569.

Amthor, J.S. 2000. The McCree-de Wit-Penning de Vries-Thornley respiration paradigms: 30 years later. Ann. Bot. 86:1-20.

Bednarz, C.W. and M.W. van Iersel. 1999. Continuous whole plant carbon dioxide exchange rates in cotton treated with Pyrithiobac. J. Cotton Sci. 3:53-59.

Björkman, O. 1981. Responses to different quantum flux densities, p. 57-107. In: O.L. Lange et al. (eds.). Encyclopedia of plant physiology. new series. vol. 12A. Physiological plant ecology I. Springer, Berlin.

Callan, E.J. and C.W. Kennedy. 1995. Intercropping stokes aster: Effect of shade on photosynthesis and plant morphology. Crop Sci. 35: $1110-1115$.

Cannell, M.G.R. and J.H.M. Thornley. 2000. Modelling the components of plant respiration: some guiding principles. Ann. Bot. 85:45-54.

Close, D.C., C.L. Beadle, and M.J. Hovenden. 2001. Cold-induced photoinhibition and foliar pigment dynamics of Eucalyptus nitens seedlings during establishment. Austral. J. Plant Physiol. 28:1133-1141.

Ehler, N. and J.M. Hansen. 1998. Plants-online-box: Monitoring whole plants net photosynthesis as a tool to evaluate plant productivity and stress in Begonia elatior var 'Ilona'. Acta Hort. 421:145-154.

Funnell, K.A., E.W. Hewett, J.A. Plummer, and I.J. Warrington. 2002. Acclimation of photosynthetic activity of Zantedeschia 'Best Gold' in response to temperature and photosynthetic photon flux. J. Amer. Soc. Hort. Sci. 127:290-296.

Giaglaras, P., M. Baille, and A. Baille. 1995. Net photosynthesis response to light and air $\mathrm{CO}_{2}$ concentration of Begonia $\times$ hiemalis: Whole plant measurements and modelling. Scientia Hort. 63:83-100.

Gifford, R.M. 1995. Whole plant respiration and photosynthesis of wheat under increased $\mathrm{CO}_{2}$ concentration and temperature. Long term vs. short term distinctions for modelling. Global Change Biol. 1:385-396.

Greenway, K.J. and V.J. Lieffers. 1997. A boreal forest grass with an open meadow photosynthetic strategy. Can. J. Bot. 75:562-567.

Hesketh J.D., D.N. Baker, and W.G. Duncan. 1971. Simulation of growth and yield in cotton: Respiration and the carbon balance. Crop 
Sci. 11:394-398.

Hesketh, J.D. and J.W. Jones. 1980. Predicting photosynthesis for ecosystem models. vol. 2. p, 69-84. CRC Press, Boca Raton, Fla.

Hikosaka, K. 1996. Effects of leaf age, nitrogen nutrition and photon flux density on the organization of the photosynthetic apparatus in leaves of a vine (Ipomoea tricolor Cav.) grown horizontally to avoid mutual shading of leaves. Planta 98:144-150.

Jones, H.G. 1992. Plants and microclimate. A quantitative approach to environmental plant physiology. 2nd ed. Cambridge Univ. Press, Cambridge, U.K.

Kessler, J.R. amd A.M. Armitage. 1992. Effects of shading on growth rate, flower initiation and flower development of Begonia semperflorens -cultorum. J. Hort. Sci. 67:849-854.

Kvet, J., J.P. Ondok, J. Necas, and P.G. Jarvis. 1971. Methods of growth analysis, p. 343-391. In: Z. Sesták, J. Catsky, and P.G. Jarvis (eds.). Plant photosynthetic production. Manual of methods. Dr. W. Junk N.V. Publishers, The Hague.

Lawlor, D.W. 1995. Photosynthesis, productivity and environment. J. Expt. Bot. 46: 1449-1461.

McCree, K.J. 1974. Equations for the rate of dark respiration of white clover and grain sorghum, as functions of dry weight, photosynthetic rate and temperature. Crop Sci. 14: 509-514.

McCree, K.J. 1982. Maintenance requirements of white clover at high and low growth rates. Crop Sci. 22:345-351.

McCree, K.J. and J.H. Troughton. 1966a. Prediction of growth made at different light levels from measured photosynthetic and respiratory rates. Plant Physiol. 41:559-566.

McCree, K.J. and J.H. Troughton. 1966b. Nonexistence of an optimum leaf area index for the production rate of white clover grown under constant conditions. Plant Physiol. 41:1615-1622.

Nemali. K.S. 2002. Optimal fertilizer concentration, water-use efficiency, and whole-plant gas exchange of subirrigated plants under varying light intensity. MS thesis. Univ. Ga., Athens.

Noguchi, K., N. Nakajima, and I. Terashima. 2001. Acclimation of leaf respiratory properties in Alocasia odora following reciprocal transfers of plants between high- and low-light environments. Plant Cell Environ. 24:831-839.

Norcini, J.G., G.W. Knox and P.C. Andersen. 1991a. Leaf gas exchange of eastern redbud (Cercis canadensis L.) grown under sun and shade.
J. Environ. Hort. 9:215-218.

Norcini, J.G., P.C. Anderson, and G.W. Knox. 1991b. Light intensity influences leaf physiology and plant growth characteristics of Photinia $\times$ fraseri. J. Amer. Soc. Hort. Sci. 116:1046-1051.

Peace, W.J.H. and P.J. Grubb. 1982. Interactions of light and mineral nutrient supply in the growth of Impatiens parviflora. New Phytol. 90:127-150.

Penning de Vries, F.W.T. 1975. The cost of maintenance processes in respiration. Ann. Bot. 39: 77-92.

Penning de Vries, F.W.T., A.H.M. Brunsting, and H.H. van Laar. 1974. Products, requirements, and efficiency of biosynthesis: A quantitative approach. J. Theor. Biol. 45:339-377.

Terry, N. and D.C. Mortimer. 2002. Estimation of the rates of mass carbon transfer by leaves of sugar beet. Can. J. Bot. 50:1049-1054.

Turgeon, R. and J.A. Webb. 1975. Leaf development and phloem transport in Cucurbita pepo: Carbon economy. Planta 123:53-62.

van Iersel, M.W. 1997. Root restriction effects on growth and development of salvia (Salvia splendens). HortScience 32:1186-1190.

van Iersel, M.W. 1999. Auxin applications affect posttransplant $\mathrm{CO}_{2}$ exchange rate and growth of vinca [Catharanthus roseus ( L.) G. Don] seedlings. J. Amer. Soc. Hort. Sci. 124: 234-238.

van Iersel, M.W. 2003. Carbon use efficiency depends on growth respiration, maintenance respiration, and relative growth rate. A case study with lettuce. Plant Cell Environ. 26:1441-1449.

van Iersel, M.W. and B. Bugbee. 2000. A multiple chamber, semicontinuous, crop carbon dioxide exchange system: Design, calibration, and data interpretation. J. Amer. Soc. Hort. Sci. 125:86-92.

van Iersel, M.W. and L. Seymour. 2000. Growth respiration, maintenance respiration and carbon fixation of vinca: A time series analysis. J. Amer. Soc. Hort. Sci. 125:702-706.

van Iersel, M.W. and J.G. Kang. 2002. Nutrient solution concentration affects whole-plant $\mathrm{CO}_{2}$ exchange and growth of subirrigated pansy. J. Amer. Soc. Hort. Sci. 127:423-429.

Vladimirova, S.V., D.B. McConnell, M.E. Kane, and R.W. Henley. 1997. Morphological plasticity of Dracaena sanderana 'Ribbon' in response to four light intensities. HortScience 32:1049-1052.

Weibel, J., E.K. Chacko, W.J.S. Downton, and P. Ludders. 1994. Influence of irradiance on photosynthesis, morphology and growth of mangosteen (Garcinia mangostana L.) seedlings. Tree Physiol. 14:263-274. 